\title{
RECIPROCITY BETWEEN GOAL ORIENTATION AND MOTIVATIONAL CLIMATE IN DIFFERENT GROUPS OF ATHLETES
}

\author{
Iveta Mitsova \\ South-West University "Neofit Rilski"
}

\begin{abstract}
One of the most widely used conceptual frameworks for studying motivation in sport is the theory of achievement goal orientation. The aim of the present study is to reveal the reciprocity between the goal orientation and the motivational climate in different groups of athletes. The subject of the research is a group of 218 athletes, practicing individual sports (track and field, orienteering, cycling, figure skating, biathlon, cross-country skiing, short track speed skating), collective sports (football, volleyball, handball) and single combat (boxing, wrestling, judo, karate). The methodological toolkit includes a Task and Ego Orientation in the Sport Questionnaire (TEOSQ) and a Perceived Motivational Climate in Sport Questionnaire-2 (PMCSQ-2). It was determined that the goal orientation towards the task and the motivational climate towards mastery dominated the studied athletes. The results of the regression analysis show that the goal orientation towards the task is determined by the component significance of the role $\left(\beta=0,467^{* *}\right)$ of the motivational climate oriented towards mastery. The goal orientation towards the ego is stimulated by the motivation-oriented component of the performance - unequal recognition $\left(\beta=0,331^{* *}\right)$. The obtained results confirm the hypothesis that the motivational climate oriented towards mastery is related to the goal orientation towards the task and respectively the motivational climate towards the performance is related to the goal orientation towards the ego.
\end{abstract}

Key words: motivation, goal orientation, mastery and performance motivational climate

\section{INTRODUCTION}

It is stated that in order to understand the motivation of an individual in physical education and sports environments, it is required to comprehend the psychological structures that energize, direct and shape achievement behavior (Roberts, 2007). One of the most widely used conceptual frameworks for studying motivation in sport is the theory of achievement goal orientation.. The approach, which assumes that individuals give meaning to achievement behaviors through the goals they have embraced, indicates that these goals reflect the aims of the effort to achieve. In other words, Achievement Goal Theory refers to goal types (aims or reasons) that guide achievement related behaviors (Roberts, 2012).

Goal orientation includes two components - task orientation and self-orientation. People with a predominant task orientation who are focused mainly on mastery and skill development are more likely to persist in failure situations, to make greater efforts, to set challenging goals, and to maintain their interest in a longer period of time towards a particular activity. However, people with a dominant ego orientation tend to concentrate their efforts on demonstrating skills in a competitive environment, and are more likely to avoid difficult tasks, they are more volatile in challenging situations, thus more often show inclination to leave the activity in a condition of difficulties. (Nicholls, 1989).

Motivational climate is considered as a regulator between goal orientation and competitor behavior. Situational factors relevant to the motivational climate in a sporting context are usually the level of intra-team member rivalry, the style of coaching instruction, the influence of significant others in the team culture, the audience and more. The perceived motivational climate is determined by two factors - a focus on mastery and a focus on performance (Ames, 1992). In a motivational, skill-oriented climate, the desire for effort, skill development and habits are highly valued, progress is judged on the basis of personal development, and mistakes are acknowledged part of the learning process. A motivational, performance-oriented climate is characterized by normative behavior, where talent and innate qualities are highly valued, competitors are punished for making mistakes or criticized for behavior (performance) that does not meet the expectations of significant others.

We assume that there is a relationship between goal 
orientation and motivational climate in different groups of athletes. Based on the theoretical framework of the theory of goal orientation, we accept that goal orientation is related to a mastery-oriented motivational climate, whereas self-orientation is related to a perceived motivational, performanceoriented climate.

The purpose of this study is to reveal the peculiarities and interrelations of goal orientation and perceived motivational climate in different groups of competitors.

Tasks of the study:

- to reveal the peculiarities of goal orientation and the perceived motivational climate in studied competitors, differentiated by gender, age, type of sport, sports experience, ranking, and participation in a different rank competitions;

- Analyze the relationships and relationships between goal orientation and motivational climate.

\section{METHODOLOGY}

Task and Ego Orientation in Sport Questionnaire
(TEOSQ), developed by Duda and Nichols (1992) to explore the target orientation in sports. The scale contains 13 questions evaluating the two dimensions of goal orientation towards achievement in sport, adapted to Bulgarian conditions. (Domuschieva-Rogleva, 2003).

Perceived Motivational Climate in Sport Questionnaire-2 (PMCSQ-2) (Newton, Duda, Yin, 2000). It consists of 33 items and a 5-point Likerttype scale for evaluation. It measures two factors - a motivational, performance-oriented (or ego-enabled) climate and a mastery (or task-involved) motivational climate adapted to Bulgarian conditions. (Domuschieva-Rogleva, 2007).

The total number of people surveyed is 218 Bulgarian athletes, representatives of the following sports: figure skating, track and field, biathlon, cross-country skiing, orienteering, short track, cycling, football, volleyball, handball, boxing, wrestling, judo and karate. For the purposes of this study, athletes are differentiated into the following groups (table 1):

Table 1. Groups of people surveyed

\begin{tabular}{|l|l|l|}
\hline \multirow{2}{*}{ Sex } & \multicolumn{1}{|c|}{ Women } & \multicolumn{1}{c|}{ Men } \\
\cline { 2 - 3 } Age & \multicolumn{1}{|c|}{$\mathbf{1 1 0}$} \\
\hline \multirow{4}{*}{ Type of sport } & from 13 to 19 y/o & 119 \\
\cline { 2 - 3 } & from 20 to 45 y/o & 99 \\
\hline \multirow{4}{*}{ Sporting experience } & Individual sports & 91 \\
\cline { 2 - 3 } & Team sports & 63 \\
\cline { 2 - 3 } & Martial arts & 64 \\
\hline \multirow{3}{*}{ Ranking } & to 3 y/o & 27 \\
\cline { 2 - 3 } & $4-5$ y/o & 43 \\
\cline { 2 - 3 } & $6-10$ y/o & 68 \\
\cline { 2 - 3 } & over 10 y/o & 80 \\
\hline \multirow{4}{*}{$\begin{array}{l}\text { Participation in different } \\
\text { ranked competitions }\end{array}$} & $1-3$ place & 189 \\
\cline { 2 - 3 } & after 3 place & 29 \\
\cline { 2 - 3 } & European Championships & 33 \\
\cline { 2 - 3 } & World Championships & 63 \\
\cline { 2 - 3 } & Olympic games & 17 \\
\hline
\end{tabular}

\section{RESULTS}

The Mann-Whitney criterion (for two samples) and Kruskal-Wallis (for more than two groups of subjects) were used to compare the experimental data between different groups of subjects. We used correlation analysis (Spearman criteria) to identify and analyze the interconnections and relationships between the variables studied. 
In the subjects surveyed, goal orientation toward the task generally prevailed $(\mathrm{M}=4,35 ; \mathrm{SD}=0,48)$ and ego orientation was less displayed $(\mathrm{M}=2,46$; $\mathrm{SD}=0,81)$. A comparative analysis of the experimental data shows that there are statistically significant differences in target orientation between the subjects surveyed, differentiated by gender, type of sport, experience and participation in different competitions. No such differences were found in the subjects, differentiated by age and ranking.

Statistically significant differences are revealed in ego orientation ( $U=2,37 ; \alpha=0,017)$, where the rate in men $(\mathrm{M}=2,58 ; \mathrm{SD}=0,77)$ are higher in compared to those in women $(\mathrm{M}=2,34 ; \mathrm{SD}=0,84)$.

There was a statistically significant difference in the two subscales for the groups of respondents divided by their participation in different sports, as follows in terms of task orientation $\left(\chi^{2}=10,32 ; \alpha=0,006\right)$ and ego orientation $\left(\chi^{2}=13,22 ; \alpha=0,001\right)$. The highest rates of task orientation are the martial arts representatives $(M=4,47 ; S D=0,52)$, followed by individual athletes $(\mathrm{M}=4,33 ; \mathrm{SD}=0,46)$ and team $(\mathrm{M}=4,25 ; \mathrm{SD}=0,44)$ sports. The tendency in ego orientation is similar to that in task orientation. The strongest ego orientation is found in the athletes of the martial arts $(\mathrm{M}=2,63 ; \mathrm{SD}=0,74)$, followed by individual $(\mathrm{M}=2,53 ; \mathrm{SD}=0,76)$ and team sports $(\mathrm{M}=2,18 ; \mathrm{SD}=0,88)$.

There is a statistically significant difference in task orientation in the differentiated sports experience groups $\left(\chi^{2}=9,98 ; \alpha=0,019\right)$. The highest rank of task orientation are athletes with sports experience of 6 to 10 years $(M=4,43 ; S D=0,44)$ and athletes with more than 10 years of experience $(M=4,41$; $\mathrm{SD}=0,45$ ). For athletes with less experience, the levels of task orientation are lower, respectively, for periods of 4 to 5 years $(\mathrm{M}=4,24 ; \mathrm{SD}=0,58)$ and the lowest levels for sports experience of up to 3 years ( $\mathrm{M}=4,15 ; \mathrm{SD}=0,41$ ).

Statistically significant differences in athletes were observed in the ego orientation of the athletes according to their participation in different rank competitions $(\chi 2=12,14 ; \alpha=0,007)$. Athletes participated in world championships with the highest values of ego orientation $(M=2,70$; $S D=0,79)$, followed by participants in European $(\mathrm{M}=2,51$; $\mathrm{SD}$ $=0,87)$, Olympic $(\mathrm{M}=2,36 ; \mathrm{SD}=0,97)$ and lastly
Republican Championships ( $\mathrm{M}=2,31$; $\mathrm{SD}=0,75)$.

The leading motivational climate in the subjects studied was generally the perceived mastery (task-involved) motivational climate $(\mathrm{M}=4,25 ; \mathrm{SD}$ $=0,43$ ), while the perceived performance-oriented motivation climate (included in the ego) was with lower ranks $(\mathrm{M}=2,75 ; \mathrm{SD}=0,61)$. With respect to the perceived motivational climate, a comparative analysis of the experimental data shows that no statistically significant differences were found between the subjects differentiated by age, sports experience, ranking and participation in different rank competitions. Such differences were found in the studied athletes differentiated by gender and type of sport.

The gender differentiated subjects revealed statistically significant differences in the cooperative learning subscales $(U=1,96 ; \alpha=0,05)$, unequal recognition $(U=1,96 ; \alpha=0,05)$, intra - team member rivalry $(U=1,96 ; \alpha=0,05)$ and a motivational, performance-oriented climate $(U=1,96 ; \alpha=0,005)$. What is striking is the fact that on all subscales, men have higher values than women. The highest values for men are the cooperative learning subscales $(M=4,14 ; S D=0,68)$, intra - team member rivalry $(M=2,99 ; S D=0,64)$, performance-oriented motivational climate $(\mathrm{M}=$ $2,82 ; \mathrm{SD}=0,59)$ and lastly unequal recognition $(\mathrm{M}=2,77 ; \mathrm{SD}=0,71)$. The values for women are as follows: cooperative learning $(\mathrm{M}=3,99$; $\mathrm{SD}=$ $0,64)$, intra - team member rivalry $(\mathrm{M}=2,84 ; \mathrm{SD}=$ $0,68)$, motivational, performance-oriented climate $(M=2,68 ; S D=0,63)$ and unequal recognition $(M$ $=2,48 ; \mathrm{SD}=0,74)$.

Statistically significant differences were found with regard to the motivational climate, with the subjects, differentiated according to the type of sport practiced, respectively, the perceived motivational climate oriented towards mastery $\left(\chi^{2}=7,55 ; \alpha=\right.$ $0,023)$ and the motivational climate oriented towards performance $\left(\chi^{2}=24,83 ; \alpha=0,001\right)$. The highest values of perceived motivational climate were revealed in martial arts contestants $(M=4,35$; $\mathrm{SD}=2,68)$, followed by collective $(\mathrm{M}=4,28$; $\mathrm{SD}$ $=0,40)$ and individual athletes $(\mathrm{M}=4,15 ; \mathrm{SD}=$ 0,42 ). In terms of the motivational climate, performance-oriented performance with the highest values is team sports $(M=3,08 ; S D=0,62)$, martial 
arts $(M=2,68 ; S D=0,53)$ and last individual athletes $(M=2,57$; $S D=0,58)$.

The results of the correlation analysis reveal significant dependencies between task orientation and a motivational mastery-oriented climate $(r=0,421$, $\mathrm{p}=0,001)$, as well as its corresponding components: significance of the role $(r=0,507, p=0,001)$, effort, and improvement $(r=0,446, p=0,001)$ and cooperative learning $(r=0,229, p=0,001)$. Ego targeting correlates with performance-oriented motivational climate $(\mathrm{r}=0,217, \mathrm{p}=0,001)$, as well as its associated subscales, unequal recognition $(r=0,302$, $\mathrm{p}=0,001)$, and intra -team member rivalry $(\mathrm{r}=$ $0,186, p=0,006)$. The results of the regression analysis show that task orientation is determined by the significance of the role component $\left(\beta=0,467^{* *}\right)$ of the mastery-oriented motivational climate. And ego targeting is stimulated by the performance-oriented component of a motivational climate - unequal recognition $\left(\beta=0,331^{\star *}\right)$.

The results of our study have established that task orientation and motivational climate for mastery dominate in all studied groups of competitors, which confirms the results of other studies in Bulgarian conditions (Domuschieva-Rogleva, 2005; Savcheva, 2019). The results obtained confirm our hypothesis that the perceived mastery of motivation-oriented learning is related to the goal-oriented task and the presentation-oriented motivational climate is the goal-oriented self, which is complemented by the results obtained from other studies (Ntoumanis, Biddle, 1998; Gencer, Ozturk, 2018).

\section{REFERENCES}

Ames, C. (1992). Achievement goals, motivational climate, and motivational processes. In G. C. Roberts (Ed.), Motivation in sport and exercise, Human Kinetics.

Domuschieva - Rogleva, G., M. Georgiev. (2005). Tseleva orientatsia i vazpriet motivatsionen klimat pri sportisti ot razlichni vidove sport. V: Lichnost, motivatsia, sport, T. 10, NSA, S., 114-122 (in Bulgarian).

Domuschieva - Rogleva, G. (2003). Aprobaciia na testa za orientaciia kym zadachata i kym sebe si (TEOSQ) $\mathrm{v}$ bylgarski usloviia. V: Lichnost, motivaciia, sport. T. 9, NSA, S. 65-71. ISBN 954-718-123-8 (in Bulgarian).

Domuschieva - Rogleva, G. (2007 a) Aprobacia na testa za vyzpriet motivacionen klimat (RMCSQ-2) v bylgarski usloviia. V: Lichnost, motivaciia, sport. T. 12, NSA, S. ., ISBN 978-954-718-208-0, 2007, 46-53 (in Bulgarian).
Domuschieva-Rogleva, G. (2009). Influence of the motivational climate on competitive anxiety with basketball players. V: Fizichka kultura, 1, Skopje, 29-31.

Duda, J.L. (1989). Relationship between task and ego orientation and the perceived purpose of sport among high school athletes. Journal of Sport and Exercise Psychology, 11.

Duda, J. L., \& Nicholls, J. G. (1992). Dimensions of achievement motivation in schoolwork and sport. Journal of Educational Psychology 3 .

Gencer, E., Ozturk, A. (2018). Goal Orientation and Motivational Climate in University Student-Athletes. Asian Journal of Education and Training, 4(4): 290-294.

Newton, M., Duda, J.L. and Yin, Z. (2000). Examination of the Psychometric Properties of the Perceived Motivational Climate in Sport Questionnaire-2 in a Sample of Female Athletes. Journal of Sports Sciences, 18, 275-290.

Nicholls, J. (1989). The competitive ethosand democratic education. Harvard University Press.

Ntoumanis, N., Biddle, S. J. H. (1998). The relationship of coping and its perceived effectiveness to positive and negative affect in sport. Personality and Individual Differences, 24, 773-788.doi:10.1016/S0191-8869(97)00240-7.

Roberts, G. C., Treasure, D. C., \& Conroy, D. E. (2007). Understanding the dynamics of motivation in sport and physical activity: An achievement goal interpretation. In G. Tenenbaum \& R. C. Eklund (Eds.), Handbook of sport psychology (pp. 3-30). Hoboken, NJ, US: John Wiley \& Sons Inc.

Roberts, G., Ommundsen, Y. (1996). Effect of goal orientation on achievement beliefs, cognition and strategies in team sport. Scandinavian Journal of Medicine \& Science in Sports, 6 (1): 46.

Roberts, G.C. (2012). Motivation in sport and exercise from an achievement goal theory perspective: After 30 years, where are we? G.C.

Savcheva, E., Dodov K. (2019). Motivational climate and participation motivation of 10-12-year-old Bulgarian pupils in physical education lessons. In: Sport Psychology, Book of Abstracts 15th European Congress of Sport ew Exercise Psychology / 15-20 July, Munster, Germany, 1. 34, pp.64.

\section{Corresponding author:}

Iveta Mitsova,

$\mathrm{PhD}$ student, South-West University "Neofit Rilski" 66 Ivan Michailov st. 2700 Blagoevgrad, Bulgaria E-mail: iveta_mitsova@abv.bg 